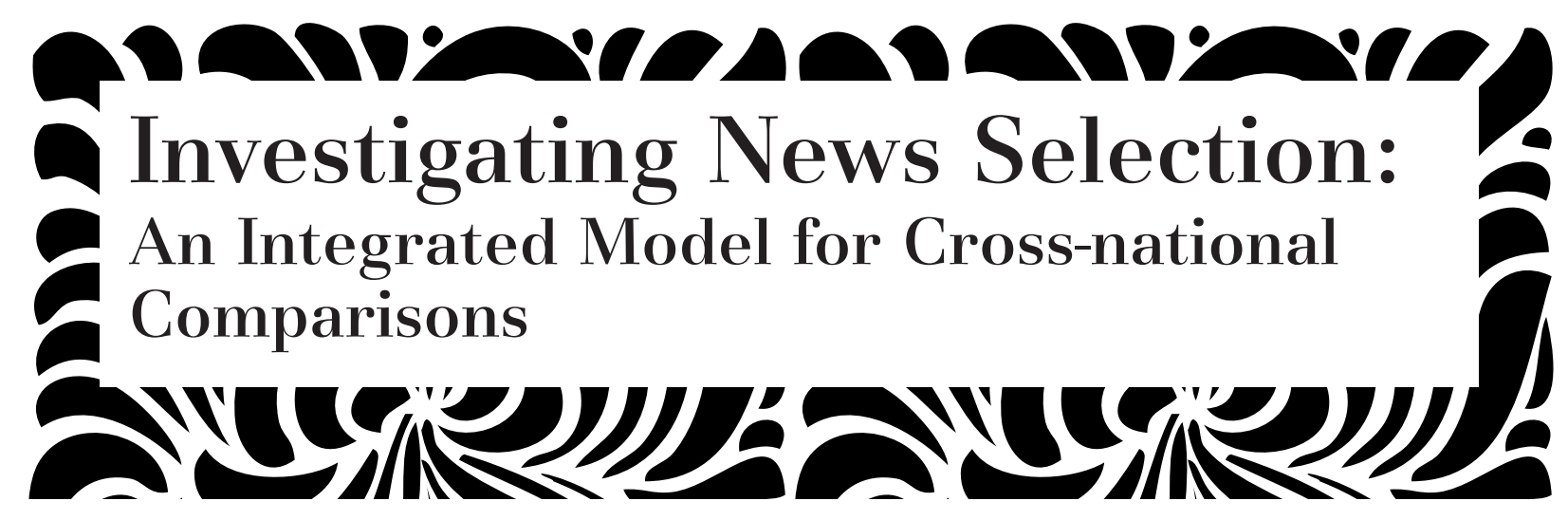

\author{
Andreas Anastasiou \\ Teaching Assistant - Doctoral Researcher \\ School of Media, Communication and Sociology \\ University of Leicester \\ United Kingdom \\ aa463@le.ac.uk
}

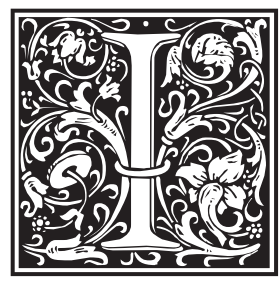

t has been argued that 'bridges' between micro- and macro-sociological perspectives are necessary at both conceptual and methodological levels, if journalistic decisions and the dynamics present during the process of news selection in different social contexts are to be effectively compared (Benson, 1999). Benson (2006; 2013) and Dickinson (2008) present detailed justifications of why Bourdieu's (1998) 'field theory', a meso-sociological approach, can effectively constitute the web connecting: a) micro-views of the journalistic practice, at the level of individual journalists or single media outlets, and b) macro-views, that explain journalistic decisions by relating them to wider political and economic factors. A field perspective, the above-mentioned papers explain, can examine the impact that both micro and macro factors have-in combination-on the process of news selection.

To make the relationship between micro and macro factors as clearly detectable as possible, I suggest that such a relationship be observed in situations of different socio-cultural contexts and be investigated in a comparative perspective and a relevant research design (Hantrais, 1999). In light of this, researchers of journalism could draw on Hallin and Mancini (2004) and select countries representing distinct media systems for their studies. Bourdieu's 'field theory'-adapted specifically to journalism by Benson $(1999 ; 2006$; 2013), referring to the relationship between the fields of journalism and (political

Pour citer cet article

Référence électronique

Andreas Anastasiou, "Investigating News Selection: An Integrated Model for Cross-national Comparisons », Sur le journalisme, About journalism, Sobre jornalismo [En ligne], Vol 6, $\mathrm{n}^{\circ} 2$ - 2017, mis en ligne le 15 décembre 2017. URL : http://surlejournalisme.org/rev 
and economic) power-, can fruitfully be combined with Hantrais's $(1995 ; 1999)$ societal approach of comparative methodology, with a focus on the relationship between the micro and the macro societal forces; and also with Hanitzsch's (2007) model of deconstructing journalistic culture, involving-among others-considerations of context and the distance (or relationship) between journalists and centres of power.

The link between these theoretical approachesthat shapes an integrated framework for the investigation and interpretation of relevant findings-is the inter-organisational perspective suggested as appropriate for the research design of comparative investigations of news selection. That is, investigating the ways political, economic, cultural and other institutions and organisations exercise their powernot on individual journalists, but rather-on the field of journalism as a whole, thus interfering in, and shaping, the internal logic of the field, and affecting its (relative anyway) autonomy.

\section{Comparative Approach}

In the same way a cross-national comparative character is suggested for investigations of news selection, a comparative methodological design that "entails studying two [or more] contrasting cases using more or less identical methods" (Bryman, 2012: 72) should also be adopted. Hantrais (1995: sec. 2, para. 1) considers an investigative project

\section{[...] to be cross-national and comparative,} when [...] particular issues or phenomena [are examined] in two or more countries with the express intention of comparing their manifestations in different socio-cultural settings [...], using the same research instruments.

Hantrais (1999: 94) has critically reviewed different methodological approaches of comparative social research, distinguishing them into 'context-free' and 'context-bounded' ones. She refers to 'universalist' approaches-in line with Dogan and Pelassy (1990) and Rose (1991)-as "grounded in the assumption that universal characteristics could be identified in social phenomena, independently from a specific context" (Hantrais, 1999: 94); criticising their attempt to test "the wider applicability of a theory developed at national level" (ibid: 95); and deeming them as producing "ill-founded inferences" because "[they ignore] specific contexts and [treat] cultural factors as exogenous variables" (ibid). She places such approaches at one end of a range of comparative approaches, viewing 'culturalist' approaches-of the Chicago School (in the 1920s and 30s) and Gar- finkel (in the 1960s)-as the other extreme, because of their "[c]laims that generalisations could be made on the basis of individual accounts" (ibid). As an effective alternative, taking an in-between way and "usefully [combining] the strong points contained in the different approaches outlined above” (ibid: 96-97), Hantrais suggests a 'societal' approach-as developed by Lammers and Hickson (1979) and further articulated by Maurice (1989) and the Aix group. The authors

\section{[...] argued that all international comparisons aim to demonstrate the effect of the national context on the object of study, but with the purpose of determining the extent to which generalisations can be made from the theoret- ical models and hypotheses that the research- er is seeking to test empirically. Therefore, [... they laid stress] on the importance of analysing the relationship between the macro and the micro (Hantrais, 1999: 96-97)}

This 'societal' approach of comparative methodological design adopted by Hantrais (1999) matches Bourdieu's (1998) 'field' theoretical approach suggested earlier as appropriate to the present project, as both aim to bridge the analytical gap between macro and micro social accounts; i.e.-in the context of this study-to co-examine the role in, and impact on, the process of news selection, of factors both internal and external to the newsroom. The perspectives of Bourdieu (1998) and Hantrais (1999) also match Hanitzsch's (2007) analytical approach of the journalistic culture in different national contexts, and a combination of the three approaches offers an appropriate thread that integrates conceptual and methodological views of comparative journalism research.

\section{InTegrating Theories AND Methods}

The assumption that individual journalists in the mainstream media have sufficient power in their hands to autonomously take decisions with respect to what is or is not news, or what news stories should or should not be given prominence (Galtung and Ruge, 1965), is challenged by the author of this paper, who suggests that the validity of this can be assessed by using the analytical model suggested here. Plenty of studies (Rosengren, 1974; Schudson, 2005; Zelizer, 2005) explain that journalists do not operate in a vacuum, but rather within a strictly structured environment, where actors of varying interests, ideas and relative power interact and have their impact on the agenda or framing of the news. On the other hand, there are theorists who argue that by looking almost exclusively at factors external 
to the newsroom (Herman and Chomsky, 1988) one can reach satisfactory explanations of the process of news selection. These approaches, reasonably, pay particular attention to issues of power and control, and tend to view journalists at large as instruments at the service of the ones who have and exercise that power.

In this paper, both views, the micro and the macro ones, though apparently opposing each other, are appreciated; at the same time, both are deemed to be in need of being complemented by one another. That is why the analytical bridge of the meso-level is adopted, accompanied by the methodological approach of combining quantitative and qualitative methods seeking to investigate the prevalence (or not) of a consensus in the journalistic field regarding the process and logic of news selection. The meso-level or field perspective (Bourdieu, 1998), considers that individual journalists (micro actors), according to their relative power, shape the field of journalism, while they are also shaped by it. In turn, the field of journalism as a whole, interacts or partially overlaps with the field of power and the fields of politics, economics and culture, all of which (along with other fields) comprise the system (at macro-level). The field (meso-level) is in contact with both the micro- and macro-levels, which do not communicate directly. Thus, the field serves as a social domain of mediation, and the sociological study of the field can offer an understanding of the interaction between micro and macro factors, that is between individual journalists and the (impersonal) system. To explain this further: the system (or even powerful persons representing it) does not interact with individual journalists on a daily basis; these persons do not (usually) examine, approve of, dictate or reject news stories in a direct manner. However, persons representing the system do maintain relationships with top actors of the media. These actors, in turn, have the power to impose rules on the journalistic field. These top-down rules, combined with bottom-up ones that have managed to establish themselves, have gradually become understood as a professional culture. This culture affects (perhaps in varying degrees) each and every journalist, who-in this way-is influenced by the system, even if he or she never actually contacts the powerful actors who represent it. The question of whether this influence process can work the other way around (from the bottom up; from the individual to the field and from the field to the system) is easy to answer: yes, it can, subject to each one's relative strength.

Contrary, then, to studies adopting 'news values' (O’Neill and Harcup, 2009) or other individual 'gatekeeping' theoretical approaches (Shoemaker and Riccio, 1991) and applying either some variant of (qualitative or quantitative) content analysis or ethnography at a (micro) media outlet level, this paper suggests filling the explanatory gap that "news values' leave uncovered (Hall et al., 1978: 54; Hartley, 1982: 79-80; Staab, 1990: 438; McQuail, 1994: 270; Allern, 2002: 139, 150) by developing a specific mixed methods combination. The appropriate research instruments are suggested to be: a survey via questionnaire and focus groups having the format of editorial meetings, as these are regularly held for the selection of the news of the day. The survey will aim to record the general patterns or prevalent views and the focus groups to assess the degree of consensus regarding the criteria of newsworthiness. The relevant research questions should trace the factors that determine: (1) the newsworthiness of 'events'; (2) the process through which fulfilment of the relevant criteria is assessed, and (3) exceptions to the application of these factors and criteria.

Furthermore, to establish a conceptual basis, facilitating a better understanding of newsworthiness and news selection, relevant investigations should touch upon the normative aspect of journalists' own understanding of their social role and mission. Thus, they could seek answers with regard to what factors facilitate or impede the implementation of such a mission (to report fully and truthfully) as widely accepted in theory (Lichtenberg, 1990; Deuze, 2005; McQuail, 2005; Singer, 2007; Hanitzsch, 2009; Reich and Hanitzsch, 2013). Answering such research questions can lead to improving the existing understanding and explanation of the process of news selection and evaluation, especially so because similarities and differences observed in countries of varying socio-cultural contexts and media systems can facilitate the establishment of patterns and clarify the causal direction between correlations of parameters. These parameters can be the 'news values'; the causal relationship examined should be whether news values cause some (objectively observed) events to be deemed newsworthy, or rather the news stories constructed in the newsrooms are given the so-called news values by journalists, during the construction process, so that they become more attractive (or more interesting, or more useful) or serve the aims-whatever these may be-of the media outlet.

As suggested by Plano Clark and Badiee (2010), a mixed methods approach can be implemented by using a main research question, assisted by two sets of sub-questions serving, respectively, the quantitative and the qualitative components of the methodological mix. A relevant, overriding research question can be: How does socio-cultural (occupational or wider) context impact journalists' decisions on news selection and evaluation? Leading to establish- 
ing an answer to this research question, two sets of secondary (partial) questions should also be asked; a quantitative set aiming to correlate factors, and a qualitative one aiming to explain processes. The quantitative set can comprise the following research sub-questions: (1) What are the main factors of newsworthiness? (2) What factors can impede the publication of an event that is deemed newsworthy? (3) What factors can lead to publishing a news story despite its non-compliance with the criteria of newsworthiness? (4) What factors, other than newsworthiness, are at play during news evaluation? (5) What is the fundamental mission of journalists? (6) What factors can override the fundamental mission of journalists? The qualitative set can seek answers to the following questions: (1) How is a degree of newsworthiness assigned to events? (2) How are news stories classed and evaluated in practice? (3) How 'close' to actors of power are journalists? (4) How does such 'closeness' impact on the news selection process? (5) How are journalists constrained or challenged in fulfilling their mission?

\section{Mixed Methods Design}

The aim, then, of the suggested cross-national investigations is to draw generalisable inferences by comparing contextual particularities of countries with different journalistic cultures, and the analytical tools adopted are: (1) a meso-sociological view, 'field theory', as a means to bridge the micro and macro theoretical approaches; (2) a combination of data collection instruments, 'mixed methods', comprising a survey and group discussion sessions simulating editorial meetings, also bridging the micro (qualitative) and macro (quantitative) methodological approaches. Bryman (1988: 147-149) suggests that a combination of quantitative and qualitative research methods can indeed serve such bridging. It can also serve in "combating [the qualitative] anecdotalism” (Bryman, 2008: 599), by using the quantitative method in order to demonstrate how prevalent the anecdotal view is; also as a means to facilitate recruitment and purposive sampling of focus group participants (ibid: 613).

On the other hand, the qualitative approach can serve in offering an explanation of data acquired via the quantitative one (ibid: 614) and especially in providing "the context for understanding broadbrush quantitative findings" (ibid: 620), an issue that is central to the aims of the research projects adopting the model suggested here. It can also shed light on the process by which an outcome (in this case, news selection) is produced (ibid: 615); and it can contribute to overcoming "the difficulty associated with inferring causal direction [of correlations derived] from a cross-sectional design” (ibid: 618). The combination of methods can thus serve all three purposes suggested by Hammersley (1996): triangulation, facilitation, and complementarity; and be-as O'Cathain et al. (2007, in Bryman, 2008: 624) suggest-"more than the sum of its parts". An integrated analysis of combined research methods can help in "legitimating inferences [validating data] and formulating generalisations” (Collins and O'Cathain, 2009: 6) through a process that Teddlie and Tashakkori (2010) have called 'inference transferability'.

Before proceeding to explain how the two research methods adopted for this investigation are combined in an integrated design and analytical schema, it would be useful to address concerns of the very possibility of such an attempt. There are scholars who, as Hughes (1990: 11), claim that

[...] every research tool or procedure is inextricably embedded in commitments to particular versions of the world and to knowing the world. To use [one method or another] is to be involved in conceptions of the world which allow these instruments to be used for the purposes conceived.

In other words, these scholars link the data gathering tools to specific ontological and (mainly) epistemological perspectives (Bryman, 1988: 118), arguing or implying that methods cannot but be determined by ontology and epistemology (Bryman, 2008: 588). The oft-cited associations are: positivism and quantitative methods-especially social survey; and interpretivist approaches and qualitative methods (ibid). However, Bryman (1988: 118-19) provides examples of studies where the qualitative ethnographic method has been applied as strong empiricism, dissociated from theoretical reflections, thus in ways not radically parting from positivism. Bryman (ibid: 120-22) also provides examples where researchers applied the quantitative method of social survey, but managed to approach questions of meaning and perception. Hansen et al. (1998: 46-48) have explained that qualitative methods, although focusing on the micro-level, do not ignore macro dimensions, as long as they do not resort to crude empiricism. On the other hand, "looking for regularities and relationships" (Niglas, 2009: 40) by applying a quantitative technique should not be a sufficient condition for viewing an investigation as distanced from an interpretivist's, social constructionist's or critical realist's perspective.

In the context of research projects adopting the character suggested here, valuing the qualitative aspect of analysing processes viewed through the eyes of the participants, I see no contradiction in 
also being interested in quantitatively inferring generalisations, as the aim should be to demonstrate whether the logic observed in the qualitative data-gathering sessions is or is not prevalent in each of the socio-cultural contexts studied. I reject, that is, the claim of a 'paradigmatic' nature of research methods (Hughes, 1990), according to which no communication between quantitative and qualitative can exist and no fusion of the two can be possible. On the contrary, I suggest a stance such as Johnson and Turner's (2003: 299) who view mixed methods positively, as long as their use involves considering their "complementary strengths and non-overlapping weaknesses"; Hammond's (2005: 240) who suggests that 'imperfections' of each type of method "can be compensated for by using an alternative" one; or Harkness et al. (2006: 78) who argue that a fusion of research techniques can "reduce the biases associated with each method".

\section{Addressing Issues of Mixed Methods}

Having established the rationale for applying a combined methods strategy, questions about a more specific design emerge, as do issues of limitations that have to be addressed. In a combined methods research strategy, decisions have to be made with respect to: (1) whether one of the methods has priority (in significance) over the other, or rather whether the design aims to integrate both in equal terms; and (2) whether the two methods run in sequence or in parallel, and the reasons for the chosen sequence (Bryman, 1988: 152; Morgan, 1998). If a higher degree of priority is assigned to one of the methods, there is an impact on the overall design, which probably tends to abide with either a mainly quantitative or mainly qualitative logic. If none of the two methods is prioritised in terms of importance, then the logic prevailing should be that of a combined and integrated implementation and analysis.

As far as the chronological sequence of applying the methods is concerned, this may be affected either by the role each of them is planned to hold (e.g. if the findings of the first are planned to be explained by conducting the second), or by practicalities of the design (e.g. if the first one is planned to serve as a means of recruitment for the second one). In the context of the suggested projects, temporal sequence has been decided on the basis of the intentions and examples mentioned above; that is, the simulation sessions are aimed to provide explanations for findings of the survey, while the survey is also used for the recruitment of focus group participants. With respect, however, to the degree of analytical importance, none of the two methods is given priority, the research design logic being that the findings of both are co-examined and co-analysed, so that a single interpretation of all data is reached (Onwuegbuzie et al., 2009: 15). Additionally, it can be said that some qualitative logic can be applied in the approach of the survey, while some quantification of qualitative data (Bryman, 2008: 596) can-cautiously-be allowed (in terms of identification of patterns), since the typicality of the purposively selected qualitative sample should allow for it. That is, storytelling based on the numerical quantitative findings can be composed, as can a thematic quantification of qualitative findings.

Two final points in the discussion of the integrated or combined research strategy concern: (1) a possible limitation, in case the results of the two methods appear to be inconsistent (Bryman, 2008: 611 ); and (2) a need to ensure that the formulation of research questions complies with the double character of the research design (Collins and O'Cathain, 2009: 4; Onwuegbuzie and Leech, 2006). Pluye et al. (2009) suggest routes of interpreting possible cases of divergence between the two methods; also four ways to address such divergence; i. reconciliation: re-examination through a new perspective or framework (ibid: 59); ii. initiation: asking new questions or collecting new data (ibid: 63); iii. bracketing: applying a plausibility 'bracket' by disregarding extreme cases (ibid); iv. exclusion: disregarding findings that cannot be justified or reporting negative results overall (ibid).

Onwuegbuzie and Teddlie (2003) and Onwuegbuzie and Leech (2006: 490-91)-having written extensively on the issue of formulating research questions specifically for mixed methods research-discuss a typology of research purposes and corresponding research questions, and recommend a seven-step model of analysis, leading to a final stage of integrating all findings into one matrix of data interpretations, thus relating the specific research project to real life. This model comprises the following stages: (a) data reduction, (b) data display, (c) data transformation, (d) data correlation, (e) data consolidation, (f) data comparison, and $(\mathrm{g})$ data integration. Plano Clark and Badiee (2010) have also written on 'Research Questions in Mixed Methods Research', and explain that a combined methods research strategy should be based on both types of questions; asking about correlations between factors (quantitative) and asking about processes (qualitative). However, they stress that "[m]ixed questions should convey the need for integration or foreshadow an integrated approach or both" (ibid: 299). The authors (ibid) discourage using separate quantitative and qualitative questions, but rather recommend "that the quantitative and qualitative aspects of a study be meaningful- 
ly related to each other, and the research questions should facilitate this process".

\section{Method I - Quantitative: Questionnaire SuRvey}

The questions included in a survey questionnaire prepared for an investigation of news selection, such as the suggested ones, have been thematically grouped so as to provide data relevant to either the theme of newsworthiness or to that of journalistic professionalism. The options for factors of newsworthiness listed in the questionnaire have been grouped in units of fairly similar meaning, to correspond to the factors most widely suggested in the literature. In this sense, Galtung and Ruge's (1965) 'threshold' has been integrated with Harcup and O'Neill's (2001) 'magnitude', Westerståhl and Johansson's (1994) ‘importance’ and Schulz's (1982) 'status' and 'valence'. Similarly, Westerståhl and Johansson's (1994) 'proximity' (be it geographic, political, cultural or temporal) has been integrated with Östgaard's (1965) 'identification', Schulz's (1982) 'dynamics', Harcup and O’Neill's (2001) 'relevance' and Galtung and Ruge’s (1965) ‘consonance’. Galtung and Ruge’s (1965) ‘composition' and Östgaard's (1965) 'simplification' were thus integrated with Cottle's (2000) and Matthew's (2010) 'form' and McGregor's (2002) television 'visualness'. Grouping these factors together does not imply that they perfectly coincide, yet I argue that their logic and understanding in practice work in a similar direction. To the widely accepted news factors I have added Schultz's (2007) technical but very interesting suggestion of 'exclusivity', which has indeed been found to be an important criterion by which journalists evaluate and select their stories. Other technical factors, which are assessed by survey questions, are Westerståhl and Johansson's (1994) 'access' and Allern's (2002) 'chance' or 'comparative availability'; lack of more important news can lead to publishing something unimportant, or abundance of important news may lead to some of it remaining unpublished.

Other parts of the questionnaire produce indications useful in assessing the journalists' sense of their own 'autonomy' (Hallin and Mancini, 2004: 14); also in assessing other aspects of journalistic professionalism, of the role of journalists in society as themselves perceive it, or as their occupational culture is 'deconstructed' by Hanitzsch (2007: 371). This institutional role comprises: (1) interventionism, with social 'intervention' and 'passiveness' placed at the two extremes of the relevant range; (2) power distance, with the 'adversarial' and the 'loyal' roles at the two sides; and (3) market orientation, according to which views about the news media audience are placed on a scale with 'consumers' and 'citizens' at its two extremes. The 'power distance' component is particularly useful for the scope of investigations interested in assessing the role of (economic, political or other) power in the process of news selection; a role that can also be assessed by studying the (institutional or inter-organisational) relationship between the field of journalism and that of power (Bourdieu, 1998; Benson, 1999; 2006; Dickinson, 2008). The remaining four components of Hanitzsch's deconstruction of journalistic culture (objectivism, empiricism, relativism and idealism) are assessed mainly through the qualitative branch of this investigation. The answers to the 'other; what?' options, included in all questions, are thematically grouped and analysed quantitatively, but they also serve as discussion points during the qualitative part of the research.

\section{Method II - Qualitative: Focus Groups}

The qualitative part of the suggested investigations aims to produce answers to the "process describing' set of the research questions, as these are suggested in this paper. The process in question is, of course, the decision-making by which journalists select what is to become a news story and what is not. It is also the process by which some news is evaluated as appropriate to be given prominence in presentation and some as being of lesser importance. In order to generate data supporting inferences with respect to the said process, the research method suggested is a set of focused group discussions simulating regular editorial meetings of a newspaper. Given the qualitative and group character of the discussion, it can be said that the process has great similarities to the focus group method (Kitzinger, 1994; Morrison, 1998; Buckingham, 2009). Given that the participants are provided with artificial news material which they are asked to evaluate, the process also approaches an experimental design (Buckalew, 1969; Helfer and Van Aelst, 2016). Given that the researcher observes the simulated news selection process keeping their own (coordinating) participation to a minimum, it can be said that elements of ethnography are also present (Schlesinger, 1978; Cottle, 2000; Willig, 2013). Finally, as editorial meetings can be viewed as management meetings of media organisations, where team leaders discuss the product to be prepared for the next day's market, research experience (simulations and role-playing games) referring to organisational and business studies is also utilised (Coombs, 1978; Faria, 2001).

The closest examples, in the literature of media studies, of a research design similar to the one proposed here, is Buckalew's (1969) analysis of television news editors' decisions, where participants were 
asked to sort a pool of news stories-corresponding to various news dimensions or factors-in rank order; and Helfer and Van Aelst's (2016) experimental study of news selection, where political journalists were asked to rate the newsworthiness of fictional political party press releases which corresponded to different news values. In both cases, the researchers analysed the findings quantitatively and established patterns of similarities and differences between editors or frequencies of correlation between editorial choices and news factors. In neither case was there any in-depth interview or group discussion between participants, so the qualitative element was not present in these (otherwise original and interesting) investigations. The Glasgow Media Group (GMG) is known for its Media-related qualitative research, involving focused group discussions which are called 'news exercises' (Philo, 1993: 257, 261). Elements of those 'news exercises' are also utilised during the proposed investigation. In the original 'news exercises' of the GMG, participants were asked to select from a number of alternative photographic captions or to produce their own ones. In the present investigation, participants are asked to opt for the most suitable one among alternative headlines of news stories. The difference between the GMG 'news exercises' and the proposed projects' ones is that the GMG investigated members of the audience wanting to draw inferences about their understanding of the news, or about "Getting the Message” as the Group's relevant book is titled (Eldridge, 1993), while in the proposed investigations professional journalists are to be involved in news selection and evaluation, or-in other words-in simulations of the process of 'sending the message'.

The scenario according to which the focus group discussions are conducted involves simulating regular editorial meetings, during which the participants-each playing the role of a newspaper section head-select or discard stories (from a pool of potential ones provided by the researcher) that will, thus, get published or not. The participants, through discussion, also decide on the prominence given to each of the selected stories, as well as on the appropriate headline to go with the main story of the front page. This process produces indications of how journalists assign a degree of newsworthiness to stories, but also allows for observing possible influences on the process exercised by factors either from within the journalistic field or external to it, namely factors related to centres of power. Cards, on which participants tick boxes or make notes are used for the economy of the process (taking optimal advantage of the available time), but moderately structured discussion is also conducted, during which the selection logic as well as possible constraints and challenges are observed.

\section{A Meso-Level Analysis \\ of Mixed Methods Findings}

The findings derived through the quantitative and the qualitative methodological approaches will be subject to an integrated mode of analysis, informed by Bourdieu's (1998), Hantrais's (1999) and Hanitzsch's (2007) combined directions for assessing the relationship between micro- and macro-level factors being at play during the process of news selection. The two (quantitative and qualitative) sets of research sub-questions produce data, which are integrated into one whole and allow for inferences to be drawn with respect to factors of newsworthiness and the logic behind them; with respect, also, to other factors and dynamics that affect journalistic choices and editorial decision making. Special attention should be paid to the potential role of (political, financial or other) power actors and the relationship (distance or proximity) journalists have with them. Being understood that power actors are not often expected to openly and directly dictate their will to individual journalists, Bourdieu's and Benson's field or meso ('mezzo' for Benson) perspective is of particular value here, as it helps the conceptualisation of influences exercised at an institutional or inter-organisational level. That is, having the fields of politics and economy as a whole exercising a force on the field of journalism, thus delimiting the latter's autonomy when making decisions on the selection and presentation of news. A consequence of this is that conditions are shaped in a way that individual journalists are obliged to choose among a limited range of 'politically correct', socially dominant or culturally hegemonic options.

Power distance is operationalised by use of both normative and pragmatic questions addressed to the participants of the investigation. The normative ones refer to the journalists' own perception of the social mission of their vocation, while the pragmatic ones are divided into two sub-categories: a) the respondents' understanding of what the norm is in the journalistic field; b) the respondents' own closeness to their sources and other actors carrying a significant weight within the field of power. The inter-organisational or meso-level of the analysis of the findings is ensured by the aggregation of quantitative data and the assessment of their statistical significance, as well as by using the group as the unit of analysis of the qualitative data. Furthermore, the field perspective is served by having a wide range of participants, representing all types and political inclinations in the mainstream news media of each one of the three countries of the study. 
Limitations-besides linguistic ones (addressed by ensuring appropriate native collaboration)-are related to the artificiality of the editorial meeting simulation process and the possible conditioning of participants in that, given that they have also participated in the first, quantitative stage, and are thusat least partly-familiar with the project's aims and objectives. The latter can be addressed by establishing an as natural as possible journalistic atmosphere during the focus group sessions.

\section{DISCUSSION}

The purpose of this paper is to propose a specific theoretical and methodological model, by use of which meaningful results can be generated. However, preliminary empirical findings-of a project applying the proposed approach-will be discussed here, their aim being to illustrate the feasibility and viability of the application of the model; also, the type of results that this is able to produce. The project involves research (through a survey of, and focus groups with, journalists) in three countries of different journalistic cultures (Hallin and Mancini, 2004): the United Kingdom, Greece and Sweden. Partial data derived from investigation in the former two will briefly be discussed here.

Asked to assess the degree of probability for an item to be published, based on the factor of it being "exclusively" held, British and Greek journalists agreed: $93 \%$ and $92 \%$ respectively replied that it would be most probable or highly probable that they would appreciate "exclusivity" and would suggest that such an item be published. On a highly technical journalistic criterion, then, an almost absolute agreement is observed. The survey goes on by asking respondents to rate the importance of various "news values"; all of which receive a fairly high degree of approval with some differences between countries. Then, journalists are asked under what condition they would publish an item, despite its non-compliance with any of the accepted "news values”. Greek journalists rated very high (much above $50 \%$ ) the factors of "pressure from public relations practitioner[s]", "wish of a political acquaintance/ news source" and "wish of important institution". British journalists gave significantly lower than 50\% ratings to the former two, while the probability of publishing something not really newsworthy when “an important institution” wishes to see it published approached $50 \%$. A remarkable agreement was also observed with the factor of "lack of more important news", which was voted for by more than $70 \%$ of the journalists in the two countries. This is another indication that journalists in different countries follow very similar technical rules, in spite of their differ- ences on their perceived degree of autonomy or on political or ethical grounds. What can be commented on here-a point that illustrates the complementarity of the two methods-is that the focus group discussion offers the opportunity to discuss what is really considered to be "important news" in the two countries, so that the survey findings can be clarified, explained or further validated. Similarly, when eight out of ten British journalists state that they would not publish an item despite its compliance with their own criteria of newsworthiness if they knew that a great part of the public would not like to see that news published-something that is true for less than five in ten Greeks-one would be tempted to use the focus groups and ask journalists how they know what the public wants published or not.

Almost all journalists in the two countries believe that the mission of journalism is to serve "truth" and "democracy". A similar, higher than 90\%, percentage is given by Greek journalists as regards serving "the citizenry”, which is lower than $80 \%$ for the British. Maybe this is one more interesting point for discussion during the focus groups. An answer to how journalism can serve "truth" and "democracy" but not to the same degree "the citizenry" could show something about the UK media. The shock, however, comes from the comparison of the above normative views of journalists with respect to the mission of journalism, to the reality as seen through the eyes of journalists. Here let the numbers speak: 100\% of Greek journalists wish that journalism serve "truth", but only $10 \%$ believe that this is the case in reality. The respective numbers for the UK are $90 \%$ and $50 \%$.

As part of the "news game" played during the focus groups, cards with potential news stories were given to the participants. Some of them deliberately included information usually classified as politically alternative or non-mainstream-in the context, however, of events organised by legitimate organisations, hosting fairly well-known speakers and attended by a fairly wide audience. The issue discussed in these events was the relationship of the country (the UK or Greece) with the European Union, an issue widely discussed and of strong public concern in both countries. The result, in both countries, was that these items were not selected for publication. When asked to justify their choice, a British journalist replied that the issue was "too complex for readers to understand and even for journalists to explain" and another one that it was "opinion rather than hard fact, which is to be preferred”. Answering a similar question, a Greek journalist replied that they would not publish this news, because "it would be irresponsible for such views to circulate". It is worth mentioning that one of the Greek participants in the focus groups did select the specific item, although he 
gave it the lowest ranking in terms of prominence. What is of great interest, however, is his reasoning: "this is an important news item, because oppositional views have to find a way to the press, if we believe in democracy. I would definitely publish it if it were in my hand. But in real life I suggest it as the news of the lowest ranking, and - even as such - I do not know whether the ones above me would accept it".

What we can observe here is a clear indication of journalists knowing their limits and knowing that they have to resort to a regular self-censorship if they are to abide with the norms of the media they work for. This became even more evident while discussing another news item, when another Greek journalist commented: "personally, I would be very much interested in it, but I have in mind the reality of the media outlet I work for. This story would not make it even as a minor one. 'It is of no interest to anybody', they would tell me”. These examples and the reality they reflect upon are indicative of how unimportant the personal views of the individual journalists are in the process of news selection. The field reality or collective journalistic culture seems to be much more important, hence the significance of the meso-level analysis proposed.

\section{Concluding Remarks}

"What is to be compared" is a reasonable question when the possibility of a comparative investigation is considered. In the case of journalism and more specifically of news selection, the answer given in this paper is: the journalistic fields. Comparing individual journalists or single newsrooms, at a micro-level, despite its value in providing rich explanations and a deep understanding of processes and routines, could have too narrow a focus, with much attention to detail and maybe missing of the greater picture. Comparing systems, on the other hand, at the macro-level, despite its value in offering a broad understanding of media environments, could leave many questions unanswered (or only partially explained) about the collective logic and the unwritten, relevant consensus prevailing in journalism. This logic and this consensus, observed at the field or meso-level, can work as a bridge of understanding and explaining attitudes of individuals in relation to dynamics of grand structures.

The methodological instrument suggested to the comparative researcher of news selection, in order to approach and investigate the meso-level or journalistic field, is the integration of a quantitative and a qualitative method (a survey and focus groups of professional journalists in different countries), drawing on a relevant theoretical framework and based on an appropriate research design. This model would examine the said consensus or collective logic of journalistic fields, by relating them to the individuals comprising such fields and the systems containing them; the theoretical assumption being that the journalistic field is shaped by forces exercised from within and outside. In turn, it can apply its own, collective force, to its individual members and the systemic structures surrounding it.

Finally, it is suggested that more research-especially comparative-is conducted in the field of journalism with a meso-sociological approach, as this level of analysis can facilitate: a) a fruitful cross-reading of important micro- and macro-analyses, abundant in the literature of media studies; b) a bridging between political-economic and culturalist interpretations of journalistic practice, both of which have greatly contributed to our understanding of journalists and journalism.

Soumission de l'article : 29/02/2016 Acceptation : 02/08/2017 


\section{BibliograPhY}

Allern, S., 2002, "Journalistic and Commercial News Values: News Organizations as Patrons of an Institution and Market Actors", Nordicom Review, vol. 23, $\mathrm{n}^{\text {os }} 1-2$, pp. 137-152.

Benson, R., 1999, "Field Theory in Comparative Context: A New Paradigm for Media Studies”, Theory and Society, vol. 28, n 3 , pp. 463-498.

Benson, R., 2006, "News Media as a 'Journalistic Field': What Bourdieu Adds to New Institutionalism, and Vice Versa”, Political Communication, vol. 23, n 2, pp. 187-202.

Benson, R., 2013, Shaping Immigration News: A French-American Comparison, Cambridge, Cambridge University Press.

Bourdieu, P., 1998, On Television and Journalism, London, Pluto Press.

Bryman, A., 1988, Quantity and Quality in Social Research, London, Routledge.

Bryman, A., 2008, Social Research Methods, 3rd ed., Oxford, Oxford University Press.

Bryman, A., 2012, Social Research Methods, 4th ed., Oxford, Oxford University Press.

Buckalew, J. K., 1969, “A Q-Analysis of Television News Editors' Decisions”, Journalism [\& Mass Communication] Quarterly, vol. 46, n 1, pp. 135-137.

Buckingham, D., 2009, “Creative' Visual Methods in Media Research: Possibilities, Problems and Proposals", $\mathrm{Me}$ dia, Culture and Society, vol. 31, n ${ }^{\circ}$ 4, pp. 633-652.

Collins, K. M., O’Cathain, A., 2009, “Introduction”, International Journal of Multiple Research Approaches, vol. 3, $\mathrm{n}^{\circ} 1$, pp. 2-7.

Coombs, D. H., 1978, "Is There a Future for Simulation and Gaming Research?” Educational Communication and Technology, vol. 26, nº 2, pp. 99-106.

Cottle, S., 2000, "New(s) Times: Towards a 'Second Wave' of News Ethnography”, Communications, vol. 25, $\mathrm{n}^{\circ}$ 1, pp. 19-42.

Deuze, M., 2005, "What is Journalism? Professional Identity and Ideology of Journalists Reconsidered", Journalism, vol. $6, \mathrm{n}^{\circ} 4$, pp. 442-464.

Dickinson, R., 2008, "Studying the Sociology of Journalists: The Journalistic Field and the News World", Sociology Compass, vol. 2, $\mathrm{n}^{\circ}$ 5, pp. 1383-1399.

Eldridge, J., 1993, "News, Truth and Power", in Eldridge, J. (Ed.), Getting the Message, London, Routledge, pp. 3-33.

Faria, A. J., 2001, "The Changing Nature of Business Simulation/Gaming Research: A Brief History”, Simulation \& Gaming, vol. 32, n 1, pp. 97-110.

Galtung, J., Ruge, M., 1965, "The Structure of Foreign News”, Journal of Peace Research, vol. 2, n 1 , pp. 64-91.

Hall, S., Critcher, C., Jefferson, T., Clarke, J., Roberts, B., 1978, Policing the Crisis: Mugging, the State, and Law and Order, London, Macmillan.

Hallin, D. C., Mancini, P., 2004, Comparing Media Systems, Cambridge University Press.
Hammond, C., 2005, “The Wider Benefits of Adult Learning: An Illustration of the Advantages of Multi-Method Research”, International Journal of Social Research Methodology, vol. 8, pp. 239-55.

Hanitzsch, T., 2007, "Deconstructing Journalism Culture: Toward a Universal Theory”, Communication Theory, vol. 17 , pp. $367-385$.

Hansen, A., Cottle, S., Negrine, R., Newbold, C., 1998, Mass Communication Research Methods, New York, Palgrave.

Hantrais, L., 1995, “Comparative Research Methods”, Social Research Update, $\mathrm{n}^{\circ}$ 13, Summer, URL: http://sru.soc. surrey.ac.uk/SRU13.html, accessed 01/05/15.

Hantrais, L., 1999, "Contextualization in Cross-national Comparative Research”, International Journal of Social Research Methodology, vol. 2, n 2, pp. 93-108.

Harcup, T., O’Neill, D., 2001, “What Is News? Galtung and Ruge Revisited”, Journalism Studies, vol. 2, $\mathrm{n}^{\circ} 2$, pp. 261-280.

Harkness, S., Moscardino, U., Bermúdez, M. R., Zylickz, P. O., Welles-Nyström, B., Blom, M., Parmar, P., Axia, G., Palacios, J., Super, C. M., 2006, "Mixed Methods in International Collaboration Research: The Experiences of the International Study of Parents, Children, and Schools", Cross-Cultural Research, vol. 40, pp. 65-82.

Hartley, J., 1982, Understanding News, London, Methuen. Helfer, L., Van Aelst, P., 2016, "What Makes Party Messages Fit for Reporting? Experimental Study of Journalistic News Selection”, Political Communication, vol. 33, $\mathrm{n}^{\circ} 1$, pp. 5-77.

Herman, E. S., Chomsky, N., 2002 [1988], Manufacturing Consent: The Political Economy of the Mass Media, New York, Pantheon Books.

Hughes, J. A., 1990, The Philosophy of Social Research, 2nd ed., Harlow, Longman.

Johnson, R. B., Turner, L. A., 2003, "Data Collection Strategies in Mixed Methods Research", in Tashakkori, A., Teddlie, C. (Eds.), Handbook of Mixed Methods in Social and Behavioral Research, Thousand Oaks, Sage, pp. 297-319.

Kitzinger, J., 1994, "The Methodology of Focus Groups: The Importance of Interaction Between Research Participants", Sociology of Health and Illness, vol. 16, $\mathrm{n}^{\circ} 1$, pp. 103-121.

Lichtenberg, J., 1990, "Foundations and Limits of Freedom of the Press", in Lichtenberg, J. (Ed.), Democracy and the Mass Media, Cambridge, Cambridge University Press, pp. 102-135.

McGregor, J., 2002, "Restating News Values: Contemporary Criteria for Selecting News”, Refereed articles from the Proceedings of the ANZCA 2002 Conference, Coolangatta, Communication: Reconstructed for the 21st Century, URL: http://mmc.twitbookclub.org/MMC911/Readings/ Week\%2003/Judy\%20McGregor\%20-\%20Final\%20Paper. PDF.pdf, accessed 21/7/2014.

McQuail, D., 1994, Mass Communication Theory: An Introduction, 3rd ed., London, Sage. 
McQuail, D., 2005, McQuail's Mass Communication Theo$r y$, 5th ed., London, Sage.

Morgan, D. L., 1998, "Practical Strategies for Combining Qualitative and Quantitative Methods: Applications for Health Research", Qualitative Health Research, vol. 8, pp. 362-76.

Morrison, D. E., 1998, The Search for a Method: Focus Groups and the Development of Mass Communication Research, Bloomington, Indiana University Press.

Niglas, K., 2009, "How the Novice Researcher can Make Sense of Mixed Methods Designs”, International Journal of Multiple Research Approaches, vol. 3, n 1, pp. 34-46.

O’Neill, D., Harcup, P., 2009, News Values and Selectivity, in Wahl-Jorgensen, K., Hanitzsch, T. (Eds.), The Handbook of Journalism Studies, Oxon, Routledge, pp. 161-174.

Onwuegbuzie, A. J., Johnson, R. B., Collins, K. M. T., 2009, "Call for Mixed Analysis: A Philosophical Framework for Combining Qualitative and Quantitative Approaches”, International Journal of Multiple Research Approaches, vol. $3, \mathrm{n}^{\circ} 2$, pp. 114-139.

Onwuegbuzie, A. J., Leech, N. L., 2006, "Linking Research Questions to Mixed Methods Data Analysis Procedures 1”, The Qualitative Report, vol. 11, $\mathrm{n}^{\circ} 3$, pp. 474-498, URL: http://nsuworks.nova.edu/tqr/vol11/iss3/3, accessed 01/05/15.

Onwuegbuzie, A. J., Teddlie, C., 2003, “A Framework for Analyzing Data in Mixed Methods Research", in Tashakkori, A., Teddlie, C. (Eds.), Handbook of Mixed Methods in Social and Behavioral Research, Thousand Oaks, Sage, pp. 351-383.

Östgaard, E., 1965, "Factors Influencing the Flow of News”, Journal of Peace Research, vol. 2, n 1, pp. 39-63.

Philo, G., 1993, "Audience Research in the Glasgow Media Group”, in Eldridge, J. (Ed.), Getting the Message, London, Routledge, pp. 253-270.

Plano Clark, V. L., Badiee, M., 2010, "Research Questions in Mixed Methods Research”, in Tashakkori, A., Teddlie, C. (Eds.), Handbook of Mixed Methods in Social and Behavioral Research, Thousand Oaks, Sage, pp. 275-304.

Pluye, P., Grad, R. M., Levine, A., Nicolau, B., 2009, "Understanding Divergence of Quantitative and Qualitative Data (or Results) in Mixed Methods Studies", International Journal of Multiple Research Approaches, vol. 3, $\mathrm{n}^{\circ}$ 1, pp. 58-72.
Reich, Z., Hanitzsch, T., 2013, "Determinants of Journalists' Professional Autonomy: Individual and National Level Factors Matter More Than Organizational Ones”, Mass Communication \& Society, vol. 16, n 1, pp. 133-156.

Rosengren, K., 1974, "International News: Methods, Data and Theory", Journal of Peace Research, vol. 11, $\mathrm{n}^{\circ} 2$, pp. 145-156.

Schultz, I., 2007, “The Journalistic Gut Feeling”, Journalism Practice, vol. 1, n 2, pp. 190-207.

Schulz, W. F., 1982, “News Structures and People's Awareness of Political Events", International Communication Gazette, vol. 30, $\mathrm{n}^{\circ}$ 3, pp. 139-153.

Schudson, M., 2005, "Four Approaches to the Sociology of News", in Curran, J., Gurevitch M. (Eds.), Mass Media and Society, 4th ed., London, Hodder Arnold, pp. 172197.

Shoemaker, P. J., Riccio, J. R., 1991, Gatekeeping, New York, Wiley.

Singer, J. B., 2007, “Contested Autonomy”, Journalism Studies, vol. 8, n 1, pp. 79-95.

Staab, J., 1990, "The Role of News Factors in News Selection: A Theoretical Reconsideration”, European Journal of Communication, vol. 5, pp. 423-443.

Teddlie, C., Tashakkori, A., 2010, "Overview of Contemporary Issues in Mixed Methods Research”, in Tashakkori, A., Teddlie, C. (Eds.), Sage Handbook of Mixed Methods in Social \& Behavioral Research, Thousand Oaks, Sage.

Westerståhl, J., Johansson, F., 1994, "Foreign News: News Values and Ideologies", European Journal of Communication, vol. 9, $\mathrm{n}^{\circ} 1$, pp. 71-89.

Willig, I., 2013, "Newsroom Ethnography in a Field Perspective”, Journalism, vol. 14, n 3 , pp. 372-387.

Zelizer, B., 2005, “The Culture of Journalism”, in Curran, J., Gurevitch, M. (Eds.), Mass Media and Society, 4th ed., London, Hodder Arnold, pp. 198-214. 


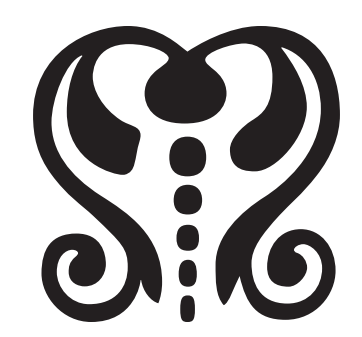




\section{Abstract | Resumé | Résumo}

\section{Investigating news selection}

An integrated model for cross-national comparisons

Étude de la sélection des actualités

Un modèle intégré pour les comparaisons transnationales

Investigando a selecão de notícias

Um modelo integrado para estudos comparativos entre países

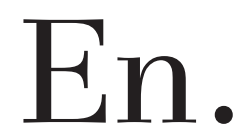

Objective: The goal of this paper is to suggest a mix of conceptual and methodological approaches through which the factors and dynamics influencing journalistic decisions during the process of news selection and evaluation are investigated in the context of countries of different journalistic cultures. Rationale: The need for devising analytical models operating at a meso-sociological level arises from the realisation that a great volume of research attempts to provide full explanations of news selection by using mainly micro or macro approaches, either of which can only partially serve that objective. Therefore, a bridge between the two is proposed here. Theoretical framework: Bourdieu's field theory, Hanitzsch's deconstruction of journalistic culture, Hantrais's comparative research design, and Bryman's logic of integrating research methods, are combined to serve the desired focus on the relationship between micro and macro societal factors. The starting point of this investigation is that the combined consideration of the theoretical domains of news values, news practice and journalistic professionalism is required, so that an adequate explanation of the dynamics of news selection and evaluation is produced. Methodology: To suit the above theoretical framework, a mixed methods approach is proposed, comprising: (1) a quantitative survey via questionnaire, establishing patterns and assessing the strength of various factors at play during news selection; (2) a qualitative focus group approach, simulating editorial meetings and shedding light on the decision-making process and the logic behind it. Conclusion: On the basis of an extensive literature review, complemented by empirical examples from an ongoing comparative research project, it is suggested that a meso-sociological approach in journalism research can bring micro- and macro-accounts of journalistic practice closer to each other.

Key-words: comparative journalism, professionalism, news practice, news values, field theory.

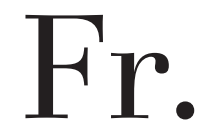

Objectif : L’objectif de cette étude est de présenter une variété d'approches conceptuelles et méthodologiques visant à mettre l'accent sur les facteurs qui influent sur les processus de sélection des actualités dans le contexte de cultures journalistiques différentes. Raisonnement : La nécessité de concevoir des modèles analytiques opérant au niveau méso-sociologique se pose du fait qu'un vaste volume de recherches tente de stipuler des explications complètes de la sélection des nouvelles en utilisant principalement des approches micro ou macro, dont l'une ne peut que partiellement servir cet objectif. Par conséquent, un rapprochement entre les deux est proposé ici. Cadre théorique : Cette étude regroupe : (1) la théorie de champs de Bourdieu ; (2) la déconstruction de la culture journalistique selon Hanitzsch ; (3) l'ébauche de la recherche comparative selon Hantrais ; (4) la logique de Bryman sur l'intégration des méthodes de recherche, et ce en vue d'élaborer la relation entre les facteurs micro- et macro-sociaux. Dans cette investigation, et comme point de départ, il est de rigueur de prendre en considération à la fois les théories des valeurs d'actualités, des pratiques d'actualités, et du professionalisme journalistique, et ce pour aboutir à une explication adéquate des dynamiques de sélection des actualités. Méthodologie : Pour convenir au cadre théorique ci-dessus, une variété d'approche de méthodes est proposée, comprenant : (1) une étude quantitative par l'intermédiaire d'un 
questionnaire, et qui a pour but d'établir des modèles et d'évaluer la prédominance de différents facteurs qui entrent en jeu durant le processus de sélection des actualités ; (2) une approche qualitative par l'intermédiaire d'un groupe de discussion, et ce en simulant des réunions éditoriales et en établissant l'importance du processus de la prise de décisions qui régit ce processus. Conclusion : Au vu d'une vaste revue de la littérature, mise à l'épreuve par des exemples empiriques d'un projet de recherche comparative en cours, il est proposé qu'une approche méso-sociologique de la recherche sur le journalisme puisse rapprocher les micro et macro-explications de la pratique journalistique.

Mots-clés : journalisme comparatif, professionnalisme, pratique d'actualités, valeurs d'actualités, théorie de champs.

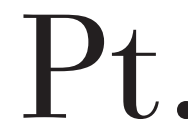

Objetivo: O objetivo deste trabalho é propor uma forma de investigar os fatores e dinâmicas que influenciam decisões editoriais tomadas no processo de avaliação e seleção de notícias, usando uma combinação de abordagens conceituais e metodológicas para um estudo comparativo entre países de culturas jornalísticas diferentes. Justificativa: A necessidade de desenvolver uma abordagem ao nível meso-sociológico decorre da constatação da existência de um grande volume de estudos dedicados a prover explicações completas do processo de seleção de noticias utilizando-se de abordagens micro ou macro, porém cada uma delas pode atender apenas de forma parcial a esse objetivo. Sendo assim, aqui se propõe uma ponte entre as duas. Arcabouço teórico: Como forma de permitir o foco desejado sobre a relação entre fatores sociais micro e macro, este estudo combina a teoria dos campos de Bourdieu, a desconstrução da cultura jornalística feita por Hanitzsch, o modelo de pesquisa comparativa de Hantrais e a lógica de Bryman para integração de métodos de pesquisa. No ponto de partida desta investigação está a visão de que se faz necessário considerar conjuntamente os campos teóricos devalor-notícia, da prática do jornalismo e da ética profissional jornalística para que se possa desenvolver uma explicação adequada da dinâmica de avaliação e seleção de notícias. Metodologia: Para adequar-se ao arcabouço teórico acima está sendo proposta uma abordagem de métodos mistos, compreendendo: (1) uma pesquisa quantitativa através de questionário, buscando identificar padrões e avaliar a importância relativa dos vários fatores em jogo durante a seleção de notícias; (2) uma abordagem qualitativa através de grupos de discussão simulando reuniões editoriais, com o objetivo de explicitar o processo de tomada de decisão e sua lógica subjacente. Conclusão: Com base em extensa revisão bibliográfica, complementada por exemplos empíricos de um projeto ainda em andamento, sugere-se que uma abordagem meso-sociológica na pesquisa em jornalismo pode aproximar visões micro e macro da prática jornalística.

Palavras-chave: jornalismo comparativo, profissionalismo, prática jornalística, valor-notícia, teoria dos campos.

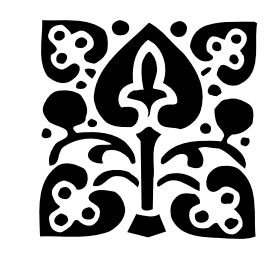

